\title{
Hiatus resolution in Xitsonga
}

\author{
Alyssa Vratsanos and Maxwell Kadenge
}

Department of Linguistics, University of the Witwatersrand, South Africa

E-mail: alyssavratsanos@gmail.com; maxwell.kadenge@wits.ac.za

\begin{abstract}
Vowel hiatus is dispreferred in many languages of the world. Xitsonga, an understudied crossborder Southern Bantu language spoken in South Africa, Mozambique, Swaziland, and Zimbabwe, employs a set of four hiatus resolution strategies: glide formation, secondary articulation, elision, and coalescence. Glide formation is the primary repair strategy, as it shows a least violation of faithfulness. In glide formation, /i/ and / $\mathrm{u} / \mathrm{correspond}$ to [j] and [w], respectively. It is blocked when $\mathrm{V}_{1}$ is preceded by a consonant, as this would incur a fatal violation of *COMPLEX. When glide formation is blocked, secondary articulation is the next preferred option. One of the interesting features of Xitsonga is that it allows secondary articulation involving mid-vowels /o e/. The Obligatory Contour Principle (OCP) is often the trigger for elision, the least preferred strategy. Vowel coalescence can take two forms in Xitsonga, namely /a $+\mathrm{i} / \rightarrow[\mathrm{e}]$ and $/ \mathrm{a}+\mathrm{u} / \rightarrow[\mathrm{o}]$, both of which incur a non-fatal violation of UNIFORMITY. When coalescence is blocked due to an impermissible sequence of /a/ and another vowel (excluding /i/ and /u/), the /a/ is elided. We argue that a single constraint hierarchy is responsible for these seemingly disjointed repair strategies. The overall significance of this paper lies in the fact that it is the first consolidated description and formal analysis of vowel hiatus resolution in Xitsonga.
\end{abstract}

Keywords: Xitsonga, hiatus resolution, Optimality Theory, repair, glide formation, elision, coalescence, secondary articulation

\section{Introduction: Hiatus resolution}

Vowel hiatus - a sequence of heterosyllabic vowels $\left(\mathrm{V}_{1} . \mathrm{V}_{2}\right)$ - is a dispreferred configuration in many languages of the world (Casali 2011). Thus, languages in which vowel hiatus is prohibited rank the markedness constraint No-HIATUS highly. In cases where a $V_{1} \cdot V_{2}$ sequence is disallowed, various repair strategies must be triggered in order to resolve this. Some of the repair strategies that have been reported in previous studies are vowel elision, assimilation, glide formation, vowel coalescence, diphthong formation (diphthongisation), and consonant epenthesis (Casali 2011). More than one strategy may be implemented within a single language, 
and some languages may even tolerate vowel hiatus in certain contexts and not others (cf. Casali 2011; Kadenge and Simango 2014; Sibanda 2009; Simango and Kadenge 2014).

Previous cross-linguistic studies have shown that hiatus is dispreferred in Bantu languages in general (Casali 2011; Mudzingwa 2010; Mudzingwa and Kadenge 2011). Mudzingwa and Kadenge (2011), for example, provide an optimality-theoretic comparative analysis of hiatus resolution in two Southern Bantu languages, chiKaranga and chiNambya, with special emphasis on glide formation, secondary articulation, and elision. In both languages, glide formation is the primary strategy, followed by secondary articulation and then elision. The main difference between the two languages lies in the strategy used when a coronal $\mathrm{V}_{1}$ is preceded by a consonant: chiNambya makes use of secondary articulation in the form of palatalisation, while chiKaranga (which bans palatalisation) deletes this vowel (Mudzingwa and Kadenge 2011). Xitsonga patterns with chiNambya in that both languages employ labialisation and palatalisation to resolve hiatus when $\mathrm{V}_{1}$ is either / $\mathrm{u} /$ or $/ \mathrm{i} /$ and is preceded by a compatible consonant.

Kadenge and Simango (2014) present a comparative analysis of vowel hiatus resolution in ciNsenga and chiShona. CiNsenga and chiShona make use of glide formation, secondary articulation, and vowel elision; chiShona also makes use of coalescence and glide epenthesis. The main difference between these two languages is that ciNsenga allows vowel hiatus in the verbal domain, while chiShona does not allow it at all. These papers show that there are crosslinguistic differences in the nature of repair strategies and the domains in which they occur in different languages. This paper seeks to contribute to phonological typology by presenting an original description and formal analysis of hiatus resolution strategies and the morphosyntactic and phonological contexts in which they operate in Xitsonga.

The remainder of the paper is organised as follows: section 2 contains a brief review of previous studies on Xitsonga grammar in general and phonology in particular. Section 3 presents a brief discussion on the geographical location, genetic affiliation, segmental, syllable structure, and morphosyntactic characteristics of Xitsonga. The analytical framework is briefly discussed in Section 4. Section 5 is the data analysis and Section 6 contains a summary of the main findings.

\section{Previous studies on Xitsonga: Identifying the gap in knowledge}

Xitsonga grammar has been somewhat neglected in the literature. Its segmental and prosodic phonology has not been analysed in detail within modern phonological theory. In many studies that deal with Bantu languages in general, Xitsonga often falls within the periphery and is usually mentioned only in passing. This is the case in Odden's (2015) comprehensive overview of Bantu phonology, in which Xitsonga is mentioned only once to point out that the process of tone tripling is also found in this language. The language is mentioned slightly more frequently in van der Spuy (1990), in which it forms a part - albeit not a large one - of a relatively superficial comparison of Bantu phonology. No explicit examples from Xitsonga are given in this study.

Studies dealing solely with Xitsonga tend to focus on its rich morphology, complex syntax, and tonomorphology. These works proved useful for the present study, in that they provided necessary background information that helped lay foundations for research into vowel hiatus resolution. Cole-Beuchat (1961) provides a description of the formation of the qualificative and 
the pronoun in Xitsonga. van Wyk (1957) explores the formation of the augmentative class in Xitsonga, with an emphasis on morphology. van Wyk, Odendaal, and Nkatini (1989) offer a basic comparison between the phonemic inventories of Xitsonga and Afrikaans, as well as a brief outline of the syllable structures of the two languages. Lee (2009) looks at the tonal system of Xitsonga, examining the ways in which the tone of a particular segment is affected by morphosyntactic processes. The tonomorphology of Xitsonga is taken up again by Lee (2015) in his analysis of high-tone spreading and depressor consonants. This is one of only a handful of recent articles on Xitsonga that use Optimality Theory (OT) as an analytical framework.

Little has been written about segmental processes in Xitsonga in general and very little on vowel hiatus resolution in particular. One study that is closely related to this article is Lee and Burheni (2014), which presents an OT- and a rule-based analysis of repair strategies in labial dissimilation in the context of diminutive formation in Xitsonga. Vowel hiatus resolution is mentioned very briefly in this article with reference to what happens when a stem ending on a vowel is suffixed by /-ana/. The main findings of this study are that in diminutive formation, rounded vowels $/ \mathrm{u} /$ and $/ \mathrm{o} /$ are changed into the glide [w] to avoid vowel hiatus. When the [w] is preceded by labial consonants, other processes occur: either the labial nasal [m] corresponds to a velar [y], or the glide deletes when preceded by labial obstruents. Lee and Burheni (2014:89) conclude that these seemingly disjunctive processes are responses to the OCP-labial constraint, according to which adjacent segments with [labial] are prohibited.

Against this background, the significance of this article is twofold. First, it aims to fill an empirical gap in linguistic research that has dealt with segmental or morphophonemic processes in general and Xitsonga vowel hiatus resolution in particular; phenomena that have previously only been dealt with peripherally in studies of the language. As mentioned earlier, Xitsonga itself has been somewhat neglected as a field of academic inquiry in recent years, with the most recent seminal studies on the language conducted in the late 1980s, and only a few follow-up studies having been conducted since (cf. Lee 2009, 2015; Lee and Burheni 2014; Janson 2001; Zerbian 2007). Secondly, the theoretical significance of the article lies in the application of OT to analyse hiatus resolution in Xitsonga. OT is currently the most widely used analytical framework in the field of phonology. Previous studies of Xitsonga phonology, with the exception of Lee and Burheni (2014), have largely been descriptive. The phonological principles used to explain hiatus resolution in Xitsonga in this article are based on universal constraints, and this draws the language into the arena of Universal Grammar (UG).

\section{Genetic affiliation and geographical location of Xitsonga}

Xitsonga $^{1}$ is a cross-border Southern Bantu language spoken in parts of South Africa, Swaziland, Mozambique, and Zimbabwe (Lee and Burheni 2014). It is one of the 11 official languages of South Africa, and is mainly spoken in the north-eastern parts of Limpopo (Lee and Burheni 2014). There are many associated dialects of Xitsonga, but the variety dealt with in the present study is that which is considered to be the standard South African form, taught in schools and used at tertiary institutions, as described by Baumbach (1987). According to Baumbach (1987), Xitsonga ought to be classified under the Nguni family of Bantu languages, given the synchronic similarities it shares with languages of this type.

\footnotetext{
${ }^{1}$ The language has also been called Thonga/Tonga, Shangaan, and Gwamba (Baumbach 1987).
} 


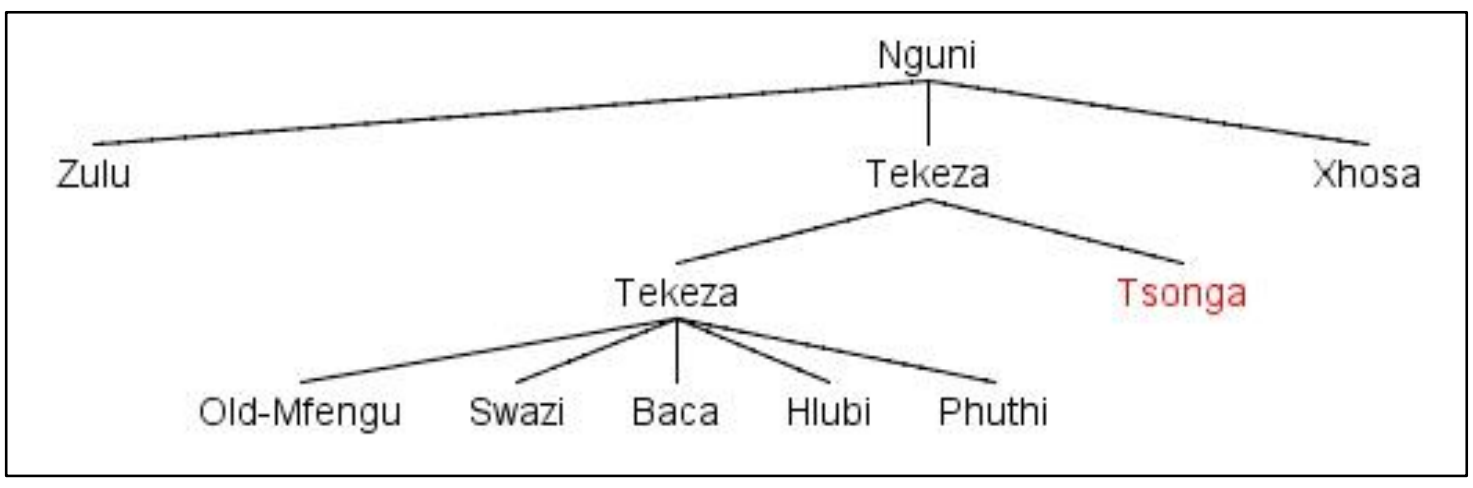

Figure 1: Xitsonga genetic classification (Baumbach 1987)

Xitsonga is classified as S50 in Guthrie's (1971) classification scheme of Bantu languages. This indicates that it is linguistically less closely related to geographically near Bantu languages such as Sesotho and isiZulu, which are grouped under S30 and S40, respectively (Zerbian 2007).

\subsection{Xitsonga vowels}

Xitsonga has a five vowel system: /a e i o u/ (Baumbach 1974; Janson 2001; van Wyk et al. 1989). The phoneme /e/ consists of two allophones [e, $\varepsilon]$, and the phoneme /o/ can in turn be realised as either [o] or [0]. A discussion of the complementary distribution of the various allophones is beyond the scope of this article. Xitsonga does not have diphthongs, suggesting that the segmental markedness constraint NO-DIPHTHONG, which militates against diphthongs (Rosenthall 1997), is undominated in this language. This explains why diphthongisation is not a viable repair strategy for vowel hiatus resolution in Xitsonga. There will be no further discussion of this constraint in this article.

\subsection{Consonants}

Xitsonga has a very large and complex consonant system. Janson (2001) presents 125 simple and complex consonant phonemes of this language. No minimal pairs are provided as evidence of the phonemic versus allophonic status of the sounds, but Janson (2001) claims that the richness and complexity of the language's consonantal system alone is enough to warrant treating each consonant and consonant variation (i.e. labialised or palatalised) as an individual segment. Table 1 below presents the simple phonemes of Xitsonga; complex consonants are discussed thereafter. 
Table 1: Consonants of Xitsonga (adapted from Baumbach 1974, 1987; Cuenod 1982; Janson 2001; van Wyk et al. 1989)

\begin{tabular}{|c|c|c|c|c|c|c|c|c|}
\hline & Bilabial & Labiodental & Alveolar & Postalveolar & Retroflex & Palatal & Velar & Glottal \\
\hline Plosive & $\mathrm{p} \quad \mathrm{b}$ & & $\mathrm{T} \quad \mathrm{d}$ & & & & $\mathrm{k} \quad \mathrm{g}$ & \\
\hline Nasal & $\mathrm{m}$ & & $\mathrm{n}$ & & & $\mathrm{n}$ & $\eta$ & \\
\hline Trill & & & $\mathrm{r}$ & & & & & \\
\hline Fricative & $\beta$ & $\mathrm{f}$ & $\mathrm{S}$ & $\int$ & $\mathrm{z}$ & & & $\mathrm{h}$ \\
\hline $\begin{array}{l}\text { Lateral } \\
\text { Fricative }\end{array}$ & & & 13 & & & & & \\
\hline Approx & & & $\mathrm{I}$ & & & $\mathrm{j}$ & & \\
\hline $\begin{array}{l}\text { Lateral } \\
\text { Approx }\end{array}$ & & & 1 & & & & & \\
\hline
\end{tabular}

Complex consonants of this language include the affricates $/ \mathrm{t} \int \mathrm{d} z \mathrm{ts} \mathrm{dz}$ ps bzl and the labialvelar approximant $/ \mathrm{w} /$. Aspirated forms of all voiceless stops and fricatives occur; prenasalised forms of most stops, affricates, and fricatives occur; labialised forms of all sounds (except those that are [labial]) occur, as do palatalised forms of all sounds that are not palatal themselves. The aspiration of fricatives in Xitsonga is marked such that an acoustic analysis of this feature could provide useful insights into the nature and character of aspiration in general. The range of consonants available to Xitsonga speakers, whether they are independent phonemes or not, is certainly very wide.

Xitsonga has one click sound. This is the alveolar click /!/, which may be realised as either voiced [ ${ }^{\mathrm{g}}$ !] or nasalized [ ${ }^{\mathrm{p} !}$ ]. This sound is only found in loanwords from isiZulu - for example, qivì [!ivi] 'swamp' - which could explain why Baumbach (1987) considered Xitsonga a Nguni variety. Moreover, tone is contrastive in Xitsonga (van Wyk et al. 1989). A minimal pair to illustrate this is mbílá 'dough' and mbílà 'dassie' (Cuenod 1982). Xitsonga has a rich tonomorphological system that has been the topic of some studies (see Lee 2009, 2015).

\subsection{Syllable structure}

A discussion of the syllable structure of Xitsonga is vital as background to the analysis of vowel hiatus resolution strategies. Xitsonga has a strict CV syllable structure (van Wyk et al. 1989). This entails a number of prerequisites: first, the onset of a syllable can be a complex consonant, but cannot be complex itself (i.e. no complex onsets). For example, [na. ${ }^{\mathrm{n}} \mathrm{g}^{\mathrm{w}} \mathrm{a}$ ] 'entrance' is viable because $\left[{ }^{\mathrm{n}} \mathrm{g}^{\mathrm{w}}\right]$ is a complex consonant and not a complex onset. However, an English word such as 'store' /sto(r)/ is not viable in Xitsonga because /st/ constitutes a complex onset, as it is a cluster of consonants. This word has been adopted into Xitsonga and 'repaired' to become [Jitolo], with the syllable shape CV.CV.CV. Vowel epenthesis rather than consonant deletion is triggered to simplify the English complex consonant cluster in Xitsonga.

Onsetless syllables are allowed in Xitsonga and are predominantly found word-initially (van Wyk et al. 1989), as in the loanword from English [1. ${ }^{\circ} \mathrm{ki}$ ] 'ink'. It is important to note that all syllables in Xitsonga are open. Thus, only syllables of the form CV and V are allowed in the language. Finally, there are no syllabic consonants in Xitsonga; all syllable peaks must be a vowel (van Wyk et al. 1989). For example, an input form /ri-va ${ }^{\mathrm{m}} \mathrm{bu} /$ 'rib' would be [ri.va. $\left.{ }^{\mathrm{m}} \mathrm{bu}\right]$ in the output, as opposed to a form that syllabifies the nasal as the syllable peak: *[ri.va.m..bu]. 


\subsection{Some aspects of Xitsonga morphosyntax}

Since different hiatus resolution strategies operate in different morphosyntactic domains, it is essential that we briefly discuss some morphosyntactic structures of Xitsonga. Xitsonga is an agglutinative language and so has an incredibly rich morphological system. Words are structured using an intricate system of affixation. Firstly, class prefixes need to be affixed to nouns, verbs, and other stems in contexts where it is necessary to indicate the class of a particular argument. These noun class prefixes and their various allomorphs (where relevant) are presented orthographically in Table 2 below.

Table 2: Noun class prefixes of Xitsonga (adapted from Baumbach 1987; Cuenod 1982)

\begin{tabular}{|c|c|c|c|c|c|}
\hline \multicolumn{2}{|c|}{ Class } & \multirow{2}{*}{$\begin{array}{l}\text { Allomorphs } \\
m-, n-, n ' w-, n^{\prime}-, \text { zero }\end{array}$} & \multicolumn{2}{|c|}{ Class } & \multirow{2}{*}{$\begin{array}{l}\text { Allomorphs } \\
v-, \text { van- }\end{array}$} \\
\hline 1 & $m u-$ & & 2 & $v a-$ & \\
\hline $1 \mathbf{a}$ & $m u-$ & $m a-, n y a-, n a-, n^{\prime} w a-$, zero & $2 \mathbf{a}$ & $v a ́-$ & $v a ́-$, plus all 1a allomorphs \\
\hline 3 & $m u-$ & $m-, n-, n^{\prime} w-, n^{\prime}-$, zero & 4 & $m i-$ & mim-, min-, min'w-, min' \\
\hline 5 & $r i-$ & $t-, d y-, d z-$, zero & 6 & $m a-$ & $m a-$, plus all 5 allomorphs \\
\hline $5 \mathbf{a}$ & dyi- & & 6a & madyi- & \\
\hline 7 & $x i-$ & $x-, c-$ & 8 & swi- & $s w-$ \\
\hline 9 & $n y-$ & $n-, m-, n^{\prime}-$, yin-, zero & $\mathbf{1 0}$ & tiny- & tin-, tim-, tin'-, tiyin- \\
\hline 11 & $r i-$ & & 10 & tim- & tin- \\
\hline 14 & $v u-$ & by-, v- & 6 & $m a-$ & maby-, mav- \\
\hline 15 & $k u-$ & $k w-, k-$ & & & \\
\hline 16 & $h a-$ & $h-$ & & & \\
\hline 17 & $k u-$ & & & & \\
\hline 18 & $m u-$ & $n-$ & & & \\
\hline
\end{tabular}

It is interesting to note that in Xitsonga no class markers are vowel-initial and there are no preprefixes (augments) as in Nguni languages. Moreover, concord markers play an important role in the language, as well as in the forthcoming discussion of vowel hiatus resolution strategies. Table 3 provides these, once again in their orthographic forms. 
Table 3: Concord markers of Xitsonga (adapted from Baumbach 1987)

\begin{tabular}{|c|c|c|c|c|}
\hline & Subject & Object & Possessive & Adjective \\
\hline 1 pers sg & $n d z i-/ n d z a-$ & $-n d z i_{-}$ & & \\
\hline 1 pers pl & hi-/ha- & $-h i-$ & & \\
\hline 2 pers $s g$ & $u-/ w a-$ & $-k u-$ & & \\
\hline 2 pers pl & $m i-/ m a-$ & $-m i-$ & & \\
\hline Cl $1 \& 1 a$ & $u-/ w a-$ & $-n ’ w i-$ & $w a-$ & lon-/n- \\
\hline Cl $2 \& 2 a$ & $v a-$ & $-v a-$ & $v a-$ & lava-/va- \\
\hline Cl 3 & $w u-/ w a-$ & $-w u-$ & $w a-$ & lowu-/wu- \\
\hline $\mathrm{Cl} 4$ & $y i-/ y a-$ & $-y i-$ & $y a-$ & leyi-/yi- \\
\hline Cl 5 & $r i-/ r a-$ & $-r i-$ & $\mathrm{ra}-$ & leri-/ri- \\
\hline Cl 5a & $d y i-/ d y a-$ & $-d y i-$ & dya- & ledyi-/dyi- \\
\hline Cl $6 \& 6 a$ & $y a-$ & $-y a-$ & $y a-$ & lama-/ma- \\
\hline Cl 7 & $x i-/ x a-$ & $-x i-$ & $x a-$ & lexi-/xi- \\
\hline Cl 8 & swi-/swa- & $-s w i-$ & swa- & leswi-/swi- \\
\hline Cl 9 & $y i-/ y a-$ & $-y i-$ & $y a-$ & leyi-/yi- \\
\hline Cl 10 & $t i-/ t a-$ & $-t i-$ & $t a-$ & leti-/ti- \\
\hline Cl 11 & $r i-/ r a-$ & $-r i-$ & $r a-$ & leri-/ri- \\
\hline Cl 14 & byi-/bya- & -byi- & bya- & lebyi-/byi- \\
\hline Cl 15 & swi-/swa- & $-s w i-$ & $k w a-$ & loku-/ku- \\
\hline
\end{tabular}

\section{Theoretical framework}

The analysis that follows is couched within OT as developed by Prince and Smolensky (2004), among many others. Optimality Theory is a constraint-based theory which holds that UG consists of a set of constraints on structural well-formedness and that individual grammars are constructed out of this set of constraints (Kager 1999). The set of possible constraints is vast and stems from language universals; an integral part of a human's genetic inheritance (Archangeli 1997). These constraints dictate what is considered well-formed within a language: markedness constraints prohibit marked surface structures like onsetless syllables, syllable codas, and complex onsets; while faithfulness constraints aim to preserve the input form as much as possible in the output. Contrast is preserved when faithfulness outranks markedness; alternations occur when markedness outranks faithfulness. The interaction of faithfulness and markedness constraints with respect to ranking determines the optimal analysis of any given input (Prince and Smolensky 2004). The relevant constraints are motivated as required at each point in the analysis. In the following section, we examine what happens when affixation creates potential vocalic hiatus in Xitsonga.

\section{Hiatus resolution in Xitsonga: Contexts and repair strategies}

In Xitsonga, vowel hiatus occurs at both the prefix-stem and stem-suffix boundaries. Four strategies are employed in Xitsonga to resolve vowel hiatus: glide formation, secondary articulation, vowel coalescence, and vowel elision. Glide formation is the preferred repair strategy in Xitsonga. When glide formation is blocked (that is, when it would result in a complex onset consisting of a sequence of a consonant and a glide), secondary articulation occurs. If secondary articulation is blocked due to phonotactic and segmental requirements, 
coalescence or elision is triggered. This study compares the strategies that are used in Xitsonga to the strategies that are used in other Bantu languages in order to contribute, in a small but significant way, to phonological typology. The following sections deal with each of these repair strategies in detail.

\subsection{Glide formation}

Glide formation is the preferred repair strategy in Xitsonga, just as it is in several other languages. In glide formation, a vowel is turned into a glide, which functions as the onset for the immediately following vowel. In Xitsonga, glide formation is evident in the formation of pronouns, as shown in Table 4 below. The formation of a pronoun involves three parts: subject concord /u-/ or /i-/; a referential formative /-o-/ or predicative element /-e-/ or /-i-/ for class 1 ; and the stabiliser element /-na/ (Baumbach 1987).

Table 4: Pronouns

\begin{tabular}{|l|c|cc|c|c|}
\hline & Class & Input & Output & Gloss \\
\hline$(1)$ & $\mathbf{1}$ & /i-e-na/ & $\rightarrow$ & {$[$ jena] } & him \\
\hline$(2)$ & $\mathbf{3}$ & $/$ u-o-na/ & $\rightarrow$ & {$[$ wona] } & it \\
\hline$(3)$ & $\mathbf{4}$ & /i-o-na/ & $\rightarrow$ & {$[$ jona] } & them \\
\hline$(4)$ & $\mathbf{6}$ & $/$ u-o-na/ & $\rightarrow$ & {$[$ wona] } & them \\
\hline$(5)$ & $\mathbf{9}$ & /i-o-na/ & $\rightarrow$ & [jona] & it \\
\hline
\end{tabular}

In each case in Table 4 above, the first vowel (which is [+high]) loses its moraicity and becomes an onset for $\mathrm{V}_{2}$. The same process is found in several other Bantu languages, including chiKaranga and chiNambya (Mudzingwa and Kadenge 2011), ciNsenga (Simango and Kadenge 2014), and chiShona (Kadenge and Simango 2014). Thus, the use of glide formation as the preferred repair strategy for vowel hiatus resolution is not uncommon in Bantu languages, and so its appearance in Xitsonga is not unsurprising. In Xitsonga, glide formation does not result in compensatory lengthening, which ultimately results in mora loss. This finding is also unsurprising, because vowel length is non-phonemic in Xitsonga. The general markedness constraint that militates against vocalic hiatus is No-HIATUS $\left(* \mathrm{~V}_{1} . \mathrm{V}_{2}\right)$, as defined in (6) below.

$$
\text { No-Hiatus }\left(* \mathrm{~V}_{1} . \mathrm{V}_{2}\right)
$$

A sequence of two vowels across a syllable boundary is prohibited

(Kager 1999)

Other constraints that are relevant to the analysis of glide formation in Xitsonga are as follows:

MAX-IO(RT)

Every input root node has a correspondent in the output

(Kadenge and Simango 2014)

$\operatorname{MAX}-\mathrm{IO}(\mu)$

Every input mora has a correspondent in the output

(Kadenge and Simango 2014) 


\section{ANCHOR L}

The leftmost root node of a morpheme in the input corresponds to a root node in the output $\left(\mathrm{V}_{2}\right.$ deletion is prohibited)

(Mudzingwa and Kadenge 2011)

\section{(10) DEP (DEPENDENCY)}

Every segment in the output has a correspondent in the input; that is, no epenthesis is permitted

(Rosenthall 1997)

An analysis of glide formation in Xitsonga is presented in Tableau 1 below.

Tableau 1: Glide formation in absolute pronouns

\begin{tabular}{|lc|c|c|c|c|c|}
\hline & /i-e-na/ & NO-HIATUS & DEP & ANCHOR L & MAX-IO(RT) & MAX-IO $(\mu)$ \\
\hline a. & & & & & $*$ \\
\hline b. $\quad[$ jena] & & & & & \\
\hline c. $\quad[$ i.na] & $* !$ & & $* !$ & $*$ & $*$ \\
\hline d. $\quad[$ i.je.na] & & $* !$ & & & $*$ \\
\hline e. $\quad[$ e.na] & & & & $* !$ & $*$ \\
\hline
\end{tabular}

Candidate (a), which turns /i/ into a glide [j], is the optimal output, as it satisfies all the highranking constraints and incurs a non-fatal violation of $\operatorname{MAX}-\operatorname{IO}(\mu)$. The resultant $[j]$ is the onset for $\mathrm{V}_{2}$. Candidate (b), which is fully faithful and has a heterosyllabic sequence of two vowels, fatally violates No-HIATUS. Candidate (c) fatally violates ANCHOR L due to the deletion of $\mathrm{V}_{2}$. Thus, Xitsonga is a $\mathrm{V}_{1}$-deleting grammar. $\mathrm{V}_{1}$ deletion is common in Southern Bantu languages (cf. Kadenge and Simango 2014; Mudzingwa and Kadenge 2011; Sibanda 2009; Simango and Kadenge 2014). Candidate (d) does well to resolve hiatus through glide epenthesis, but is nonoptimal because it crucially violates DEP. Segment epenthesis is not an optimal repair strategy for resolving vocalic hiatus in Xitsonga. The $\mathrm{V}_{1}$-deleting candidate (e) is less optimal than the glide formation one (a). Glide formation is thus the preferred repair strategy, as it retains most of the features of $V_{1}$, thereby remaining largely faithful to the input (Rosenthall 1997). However, when $\mathrm{V}_{1}$ is preceded by a consonant, glide formation is blocked, as a complex onset (CC) would be formed. Complex onsets are dispreferred in Xitsonga. When glide formation is blocked, secondary articulation is the next preferred option.

\subsection{Secondary articulation}

When $\mathrm{V}_{1}$ is preceded by a consonant, glide formation is blocked, as a sequence consisting of a consonant and a glide results in a complex onset, which is prohibited in Xitsonga. Once again, the prohibition of complex onsets in Xitsonga is not surprising, given its prevalence in other Bantu languages, including ciNsenga, chiNambya, siSwati, chiKaranga, and isiZulu (see Kadenge 2015; Kadenge and Simango 2014; Mudzingwa and Kadenge 2011, 2014; Simango and Kadenge 2014). Thus, the following constraint is undominated in these languages: 


\author{
*COMPLEX \\ Complex onsets are prohibited
}

(Kager 1999)

Secondary articulation involves a high vowel /i u/ surfacing as non-moraic in the output (Rosenthall 1997) so that the vowel hiatus is resolved and the resulting monophthong $\left(\mathrm{V}_{2}\right)$ has a simple onset. Secondary articulation results in root node and mora loss (Rosenthall 1997). The variety of Xitsonga under investigation exhibits extensive evidence of labialisation, which occurs when $\mathrm{V}_{1}$ is rounded, and palatalisation, which occurs when $\mathrm{V}_{1}$ is unrounded. Constraints (6) through (11) above are pertinent to the analysis of secondary articulation. Labialisation is most notably found in the creation of diminutives (suffixation of /-ana/), when the noun stem ends on a rounded vowel /o $\mathrm{u} /$ and is not itself preceded by an oral labial consonant (Lee and Burheni 2014). Table 5 below provides some examples illustrating labialisation.

Table 5: Labialisation in diminutives

\begin{tabular}{|c|c|c|c|}
\hline & Input & & Output \\
\hline (12) & $\begin{array}{l}\text { //1̂̀-pótó-áná/ } \\
\text { CL7-pot-DIM }\end{array}$ & $\rightarrow$ & $\begin{array}{l}\text { [Jìpót'áná] } \\
\text { 'small pot' }\end{array}$ \\
\hline (13) & $\begin{array}{c}\text { /Jì-tóló-ánál } \\
\text { CL7-store-DIM }\end{array}$ & $\rightarrow$ & $\begin{array}{l}\text { [Jìtól'áná] } \\
\text { 'small store' }\end{array}$ \\
\hline (14) & 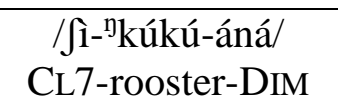 & $\rightarrow$ & 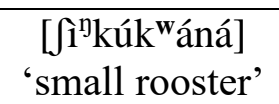 \\
\hline (15) & $\begin{array}{c}\text { / /î-gàgú-áná/ } \\
\text { CL7-porridge-DIM }\end{array}$ & $\rightarrow$ & $\begin{array}{c}\text { [ } \text { [ìgàgwáná] } \\
\text { 'small porridge' }\end{array}$ \\
\hline (16) & $\begin{array}{l}\text { /sì-dzànù-áná/ } \\
\text { CL7-sense-DIM }\end{array}$ & $\rightarrow$ & $\begin{array}{l}\text { [sìdzànwáná] } \\
\text { 'small sense' }\end{array}$ \\
\hline
\end{tabular}

In each case in Table 5 above, there is a sequence of $/ \mathrm{C}_{\text {[-labial] }} \mathrm{V}_{\text {[+round]-ana/ which becomes }}$ $\left[\mathrm{C}^{\mathrm{w}}\right.$ ana] in the output. It is interesting to note that the mid-vowel $/ \mathrm{o} / \mathrm{can}$ also participate in secondary articulation in Xitsonga. In many Southern Bantu languages, mid-vowels do not participate in glide formation and secondary articulation (cf. Kadenge and Simango 2014; Mudzingwa and Kadenge 2011; Sibanda 2009; Simango and Kadenge 2014). In Xitsonga, the ability of a vowel to glide is not so much reliant on its height, but rather on lip rounding. In other words, the important feature for secondary articulation is not the [+/- high] feature, but the [+/- round] feature. For example, in chiShona and ciNsenga, labialisation can only occur with the high vowel /u/ (Kadenge and Simango 2014), not with the mid-vowel /o/, which is evidently possible in Xitsonga. Tableau 2 below presents an analysis of labialisation in Xitsonga. 
Tableau 2: Labialisation of rounded vowel /o/

\begin{tabular}{|c|c|c|c|c|c|}
\hline //1̀-pótó-áná/ & No-HiATUS & *COMPLEX & DEP & MAX-IO(RT) & $\operatorname{MAX}-\mathrm{IO}(\mu)$ \\
\hline [or.pó.tª́.ná] & & & & $*$ & $*$ \\
\hline [jì.pó.twá.ná] & & $* !$ & & & $*$ \\
\hline [Jì.pó.to.á.ná] & $* !$ & & & & \\
\hline [Jì.pó.to.Pá.ná] & & & $* !$ & & \\
\hline
\end{tabular}

In Tableau 2, output candidates (b), (c), and (d) each incur a fatal violation of a high-ranking constraint. Glide formation in (b) results in a complex onset for $\mathrm{V}_{2}$, thus fatally violating *COMPLEX. Heterosyllabification, as in (c), fatally violates NO-HiATUS. Candidate (d) indicates that consonant epenthesis is non-optimal, as it violates DEP. Therefore, the optimal candidate (a) is that which violates the low-ranking constraints - in this case, the loss of a root node and the loss of a mora. It seems that labialisation is the optimal strategy to resolve vowel hiatus in a sequence of an onsetful rounded vowel /o u/ and another $\mathrm{V}$, in this case the /-a/ of the diminutive suffix. However, in order to satisfy a highly ranked OCP constraint, a rounded $\mathrm{V}_{1}$ may be elided when preceded by an oral labial consonant. The OCP, in essence, prohibits segments with the same features appearing adjacent to one another (McCarthy 1988). When the consonant preceding the rounded $\mathrm{V}_{1}$ is the bilabial nasal $/ \mathrm{m} /$, a process of labial dissimilation in the form of velarisation of the nasal (see Lee and Burheni 2014 for a detailed discussion) occurs. Some illustrative examples of this are presented in Table 6 below.

Table 6: Labial dissimilation in diminutives (see Lee and Burheni 2014:94)

\begin{tabular}{|c|c|c|c|}
\hline & Input & & Output \\
\hline (17) & $\begin{array}{l}\text { /Ji-gomo-ana/ } \\
\text { CL7-forehead-DIM }\end{array}$ & $\rightarrow$ & $\begin{array}{l}\text { [Jigon"ana] } \\
\text { 'small forehead' }\end{array}$ \\
\hline (18) & $\begin{array}{l}\text { //1-nomo-ana/ } \\
\text { CL7-mouth-DIM }\end{array}$ & $\rightarrow$ & $\begin{array}{l}{\left[\int_{\text {inon}}{ }^{\mathrm{w}} \text { ana }\right]} \\
\text { 'small mouth' }\end{array}$ \\
\hline (19) & $\begin{array}{l}/ \int 1-{ }^{n} \text { somo-ana/ } \\
\text { CL7-seam-DIM }\end{array}$ & $\rightarrow$ & $\begin{array}{l}{\left[\int^{\mathrm{n}} \text { son }^{\mathrm{w}} \text { ana }\right]} \\
\text { 'small seam' }\end{array}$ \\
\hline (20) & $\begin{array}{l}/ \int 1-{ }^{n} \text { simu-ana/ } \\
\text { CL7-field-DIM }\end{array}$ & $\rightarrow$ & $\begin{array}{l}{\left[\int^{\mathrm{n}} \sin ^{\mathrm{w}} \text { ana }\right]} \\
\text { 'small field' }\end{array}$ \\
\hline (21) & $\begin{array}{l}\text { //1i-namu-ana/ } \\
\text { CL7-neck-DIM }\end{array}$ & $\rightarrow$ & $\begin{array}{l}\left.\text { [Jinay }{ }^{\mathrm{w}} \text { ana }\right] \\
\text { 'small neck' }\end{array}$ \\
\hline (22) & $\begin{array}{l}/ \int \mathrm{i} \text {-simu-ana/ } \\
\text { CL7-song-DIM }\end{array}$ & $\rightarrow$ & $\begin{array}{l}\left.\text { [Jisin }{ }^{\mathrm{w}} \text { ana }\right] \\
\text { 'small song, }\end{array}$ \\
\hline
\end{tabular}

Labial dissimilation in Xitsonga is a response to an OCP-driven constraint, defined in (23) below, which prohibits the surfacing of a sequence of identical features, such as the realisation of the labial nasal $/ \mathrm{m} /$ as $*\left[\mathrm{~m}^{\mathrm{w}}\right]$. This constraint obviously dominates the identity or faithfulness constraint that prohibits place of articulation changes, as defined in (24).

(23) OCP

A sequence of identical features is prohibited

(McCarthy 1988) 
The interaction of these constraints is illustrated in Tableau 3 below.

Tableau 3: Labial dissimilation and labialisation

\begin{tabular}{|c|c|c|c|c|c|c|}
\hline$/ \int 1$-gomo-ana/ & $\begin{array}{l}\text { No- } \\
\text { HIATUS }\end{array}$ & *COMPLEX & $\mathrm{OCP}$ & MAX-IO(RT) & $\begin{array}{l}\text { MAX- } \\
\mathrm{IO}(\mu)\end{array}$ & $\begin{array}{c}\text { IDENT- } \\
\text { IO(PLACE) } \\
\text { NASAL } \\
\end{array}$ \\
\hline a. $\left[\int 1 . g o . n^{\mathrm{w}} a . n a\right]$ & & & & $*$ & $*$ & $*$ \\
\hline b. [fi.go.mo.a.na] & $* !$ & & & & & \\
\hline c. [Ji.go.mwa.na] & & $* !$ & & & $*$ & \\
\hline d. [Ji.go.m ${ }^{\mathrm{w}}$ a.na $]$ & & & $* !$ & $*$ & $*$ & \\
\hline
\end{tabular}

From Tableau 3, it is evident that labial dissimilation and labialisation are viable repair strategies in Xitsonga. The winner, candidate (a), which triggers labialisation and velarisation, satisfies all the high-ranking constraints. All the remaining candidates fatally violate an undominated constraint. Of note is (d), which involves labialisation, but of a bilabial nasal. This fatally violates OCP and is repaired by labial dissimilation, as in (a). In addition to labialisation, Xitsonga also exhibits interesting cases of palatalisation. See Table 7 below for some of the examples of diminutive formation with stems ending with $/ \mathrm{l} /, / \mathrm{r} /{ }^{2}, / \mathrm{vo} /, / \mathrm{vi} /, / \mathrm{vu} /, / \mathrm{m} \mathrm{be} /$, or $/{ }^{\mathrm{m}} \mathrm{bu} /{ }^{3}$

Table 7: Palatalisation in diminutives /-ana/ (Baumbach 1987)

\begin{tabular}{|c|c|c|c|}
\hline & Input & & Output \\
\hline$(25)$ & $\begin{array}{l}\text { Ji-t } \int u r i-a n a \\
\text { CL7-mortar-DIM }\end{array}$ & $\rightarrow$ & $\begin{array}{l}\text { Jitfud'ana } \\
\text { 'small mortar' }\end{array}$ \\
\hline (26) & $\begin{array}{l}\text { Ji-muri-ana } \\
\text { CL7-tree-DIM }\end{array}$ & $\rightarrow$ & $\begin{array}{l}\text { Jimudiana } \\
\text { 'small tree' }\end{array}$ \\
\hline (27) & $\begin{array}{l}\text { Ji-nkavi-ana } \\
\text { CL7-switch-DIM }\end{array}$ & $\rightarrow$ & $\begin{array}{l}\int^{\mathrm{n}} \mathrm{kab}^{\mathrm{j}} \text { ana } \\
\text { 'small switch' }\end{array}$ \\
\hline (28) & $\begin{array}{l}\text { Ji-nkombe-ana } \\
\text { CL7-spoon-DIM }\end{array}$ & $\rightarrow$ & $\begin{array}{l}\int^{\mathrm{n}} \mathrm{ko}^{\mathrm{m}} \mathrm{b}^{\mathrm{j}} \text { ana } \\
\text { 'small spoon' }\end{array}$ \\
\hline
\end{tabular}

In each case, the high vowel/i/ and the mid-vowel/e/ are palatalised to the preceding consonant. Note again the ability of the mid-vowel /e/ to participate in secondary articulation. Other phonological processes are also at work, resulting in a change from $/ \mathrm{r} / \rightarrow[\mathrm{d}]$ and $/ \mathrm{v} / \rightarrow[\mathrm{b}]$. In this analysis, this sound change is accounted for by means of a low-ranking faithfulness constraint which prohibits changes in manner of articulation, as defined in (29) below:

\section{IDENTITY-IO(MANNER)}

Manner of articulation is preserved in the output

\footnotetext{
${ }^{2}$ Also when realised as murmured.

${ }^{3}$ These are monosegmental prenasalised consonants [ $\left.{ }^{\mathrm{m}} \mathrm{b}\right]$.
} 
The low-ranking segmental markedness constraint which prohibits the palatalisation of consonants is given in (30) below.

$$
\begin{aligned}
& * \mathrm{C}^{\mathrm{j}} \\
& \text { Palatal consonants are prohibited }
\end{aligned}
$$

(Sibanda 2009)

\begin{tabular}{|c|c|c|c|c|c|c|c|}
\hline$/ \int \mathrm{i}-\mathrm{t} \int \mathrm{uri}$-ana/ & $\begin{array}{l}\text { No- } \\
\text { HiATUS }\end{array}$ & *COMPLEX & DEP & $\begin{array}{l}\text { MAX- } \\
\text { IO(RT) }\end{array}$ & $\begin{array}{l}\text { MAX- } \\
\mathrm{IO}(\mu)\end{array}$ & $* \mathrm{C}^{\mathrm{j}}$ & $\begin{array}{c}\text { IDENT- } \\
\text { IO(MANNER) }\end{array}$ \\
\hline a. $\left.\quad \cos . t \int u . d^{\mathrm{j}} a . n a\right]$ & & & & $*$ & $*$ & $*$ & $*$ \\
\hline b. [Ji.tfu.ri.a.na] & $* !$ & & & & & & \\
\hline c. [Ji.tsu.di.ja.na] & & & $* !$ & & & & * \\
\hline d. [ [ji.tfu.dja.na] & & $* !$ & & & $*$ & & $*$ \\
\hline
\end{tabular}

Tableau 4: Palatalisation in diminutive formation

In Tableau 4 above, the optimal candidate uses palatalisation to resolve hiatus. Since Xitsonga does not permit palatalised [r] and [v], it plosivises them into [d], which is compatible with palatalisation. As a consequence, it violates the low-ranking identity constraint IDENTIO(MANNER). The winning candidate, (a), incurs four non-fatal violations in order to satisfy high-ranking constraints. Heterosyllabification incurs a fatal violation of No-HIATUS, as in (b). Glide epenthesis, in (c), fatally violates DEP; and glide formation, as in (d), results in a complex onset for $\mathrm{V}_{2}$, thus fatally violating *COMPLEX. When neither glide formation nor secondary articulation can take place, vowel coalescence may be possible in order to resolve the vowel hiatus. This is explored in the next section.

\subsection{Vowel coalescence}

Vowel coalescence involves a non-high $\mathrm{V}_{1}$ coalescing with a high $\mathrm{V}_{2}$ to become another nonhigh vowel (Casali 2011). This vowel $\left(V_{3}\right)$ is identical to $V_{2}$ in every respect except height or aperture (Mudzingwa and Kadenge 2014). Only coalescence in the form /a $-\mathrm{i} / \rightarrow$ [e] and /a $\mathrm{u} / \rightarrow[\mathrm{o}]$ are found in Xitsonga. These patterns are widely attested in Bantu languages (see Harford 1997; Miti 2001, 2002; Mudzingwa and Kadenge 2014; Sibanda 2009, and references in these publications), and so their occurrence in Xitsonga is to be expected. Coalescence of the form $/ \mathrm{a}-\mathrm{i} / \rightarrow[\mathrm{e}]$ is evident in three contexts: affixing noun class prefixes to nominals; affixing possessive concord markers to the possessive pronoun stem of first-person and second-person plural; and when forming locatives of nouns ending in /-a/. Examples of each of the aforementioned cases are given in Tables (8) through (11) below.

Table 8: Vowel coalescence in noun class prefixation

\begin{tabular}{|l|ll|l|}
\hline & Input & Output \\
\hline$(31)$ & /ma-ínó/ & $\rightarrow$ & $\begin{array}{l}\text { [ménú] } \\
\text { 'teeth' }\end{array}$ \\
& CL6-tooth & $\rightarrow$ & [vénú] \\
& 'va-ínú/ & 'owners' \\
\hline$(32)$ & CL2-owner & $\rightarrow$ & \\
&
\end{tabular}


Table 9: Vowel coalescence in possessive formation

\begin{tabular}{|l|l|l|l|l|l|}
\hline & Input & & Output & Example & Gloss \\
\hline$(33)$ & /va-iru/ & $\rightarrow$ & {$[$ veru $]$} & vana veru & 'our children' \\
\hline$(34)$ & /va-inu/ & $\rightarrow$ & {$[$ venu $]$} & vana venu & 'your children' \\
\hline
\end{tabular}

Table 10: Vowel coalescence in locative formation

\begin{tabular}{|c|c|c|c|}
\hline & Input & & Output \\
\hline (35) & $\begin{array}{l}\text { /a- }{ }^{n} \text { dzava-ini/ } \\
\text { a-mountain-Loc }\end{array}$ & $\rightarrow$ & $\begin{array}{l}\text { [a dzaveni] } \\
\text { 'at the mountain' }\end{array}$ \\
\hline
\end{tabular}

Coalescence in the form /a $-\mathrm{u} / \rightarrow[\mathrm{o}]$ is significantly less prevalent. The following examples will suffice to illustrate it:

Table 11: Vowel coalescence in first-reference demonstratives

\begin{tabular}{|c|c|c|c|}
\hline & Input & & Output \\
\hline (36) & $\begin{array}{l}\text { /la-u-ku/ } \\
\text { REV-V-PREF }\end{array}$ & $\rightarrow$ & $\begin{array}{l}\text { [loku] } \\
\text { 'this' }\end{array}$ \\
\hline (37) & $\begin{array}{l}\text { /la-u-mu/ } \\
\text { REV-V-PREF }\end{array}$ & $\rightarrow$ & $\begin{array}{l}\text { [lowu] } \\
\text { 'this' }\end{array}$ \\
\hline
\end{tabular}

The demonstratives given in Table 11 consist of the demonstrative affix /la-/, then a vowel based on that of the relevant noun class prefix, and finally the noun class prefix itself. Example (37) involves another sound change, $-/ \mathrm{m} / \rightarrow[\mathrm{w}]$, which would incur a non-fatal violation of IDENT-IO (MANNER). We invoke the additional constraints defined in (38) and (39) below for the analysis of vowel coalescence.

(38) $\quad * \mathrm{C}^{\mathrm{\varsigma}}$

No pharyngealised consonants

(39) UNIFORMITY

(Mudzingwa and Kadenge 2014)

A segment in the output cannot have more than one correspondent in the input

(Kager 1999)

UNIFORMITY ultimately prevents the merging of two segments, linking it directly to a discussion of vowel coalescence. Tableau 5 below presents an analysis of vowel coalescence using example (31) from Table 8: /ma-ínó/ $\rightarrow$ [ménú] 'teeth'. 
Tableau 5: Vowel coalescence $/ \mathrm{a}+\mathrm{i} / \rightarrow[\mathrm{e}]$

\begin{tabular}{|c|c|c|c|c|c|c|c|}
\hline /ma-ínó/ & $\begin{array}{c}\text { No- } \\
\text { HIATUS }\end{array}$ & *COMPLEX & $* \mathrm{C}^{\varsigma}$ & DEP & $\begin{array}{l}\text { MAX- } \\
\text { IO(RT) }\end{array}$ & UNIFORM & $\begin{array}{l}\text { MAX- } \\
\mathrm{IO}(\mu)\end{array}$ \\
\hline $\begin{array}{l}\text { a. } \quad[\text { ménú] } \\
\end{array}$ & & & & & $*$ & $*$ & $*$ \\
\hline b. [ma.ínó] & $* !$ & & & & & & \\
\hline c. [ma.ji.nó] & & & & $* !$ & & & \\
\hline d. [mi.nó] & & & $* !$ & & $*$ & & $*$ \\
\hline e. [msi.nó] & & $* !$ & & & & & $*$ \\
\hline
\end{tabular}

In Tableau 5 above, the coalescence candidate, (a), is the winner, as it incurs only low-ranking faithfulness violations of MAX-IO(RT), UNIFORMITY, and MAX-IO $(\mu)$, in order to satisfy the more highly ranked constraints that are fatally violated by output candidates (b), (c), (d), and (e). Heterosyllabification incurs a fatal violation of No-HIATUS, as in (b); while glide epenthesis results in a fatal violation of DEP. The presence of $/ a /$ as $V_{1}$ results in secondary articulation and glide formation in (d) and (e), respectively, which in turn incur fatal violations of markedness constraints $* C^{\mathcal{S}}$ and $*$ COMPLEX. The analysis presented in Tableau 5 can be applied mutatis mutandis to coalescence of the form $/ \mathrm{a}+\mathrm{u} / \rightarrow[\mathrm{o}]$.

\subsection{Vowel elision}

Vowel elision involves the loss of all of the features of one of the vowels in hiatus. In Xitsonga, as well as cross-linguistically (Casali 2011), the elision of $\mathrm{V}_{1}$ is more common than that of $\mathrm{V}_{2}$. First, it is evident when affixing noun class prefixes with a noun stem beginning with a vowel (Baumbach 1974):

Table 12: $\mathrm{V}_{1}$ elision in noun class prefixation

\begin{tabular}{|c|c|c|c|}
\hline & Input & & Output \\
\hline (40) & $\begin{array}{l}\text { /va-aki/ } \\
\text { CL2-builder }\end{array}$ & $\rightarrow$ & $\begin{array}{l}\text { [vaki] } \\
\text { 'builders' }\end{array}$ \\
\hline (41) & $\begin{array}{l}\text { /mu-usi/ } \\
\text { CL3-smoke }\end{array}$ & $\rightarrow$ & $\begin{array}{l}\text { [musi] } \\
\text { 'smoke' }\end{array}$ \\
\hline (42) & $\begin{array}{l}/ \int \mathrm{i}-\mathrm{a}^{\mathrm{n}} \mathrm{Ba} / \\
\text { CL7-hand }\end{array}$ & $\rightarrow$ & $\begin{array}{l}{\left[\mathrm{Ja}^{\mathrm{n}} \mathrm{Ba}\right]} \\
\text { 'hand' }\end{array}$ \\
\hline (43) & $\begin{array}{l}\text { /si-ambalo/ } \\
\text { CL8-uniform }\end{array}$ & $\rightarrow$ & $\begin{array}{l}\text { [sambalo] } \\
\text { 'uniforms', }\end{array}$ \\
\hline (44) & $\begin{array}{l}\text { /ri-endzo/ } \\
\text { CL11-journey }\end{array}$ & $\rightarrow$ & $\begin{array}{l}{\left[\mathrm{re}^{\mathrm{n}} \mathrm{d} z \mathrm{o}\right]} \\
\text { 'journey' }\end{array}$ \\
\hline
\end{tabular}

In each case presented in Table 12, the first vowel is elided completely, which results in mora, V-Place node, and root node loss. As mentioned earlier, a mora is lost as Xitsonga has no compensatory lengthening; a phenomenon found mostly in languages in which vowel length is contrastive, such as Luganda (Rosenthall 1997). Thus, Xitsonga always satisfies the markedness constraint often termed *V: (Kadenge and Simango 2014; Mudzingwa and Kadenge 2014) or NoLONGVowel (NLV) (Rosenthall 1997). In other words, as is the case 
with ciNsenga and chiShona, ${ }^{*} \mathrm{~V}$ : is undominated in Xitsonga. Given this explanation, to include this constraint in the OT analysis presented in this study would be redundant; thus the reader need only remember that compensatory lengthening does not occur in Xitsonga. Tableau 6 below illustrates the elision of $/ u$ / in Xitsonga.

Tableau 6: Elision of /u/ following labial nasal /m/

\begin{tabular}{|c|c|c|c|c|c|c|}
\hline$/ \mathrm{mu}_{1}-\mathrm{u}_{2} \mathrm{si} /$ & $\begin{array}{c}\text { No- } \\
\text { HiATUS }\end{array}$ & *COMPLEX & OCP & ANCHOR L & MAX-IO(RT) & $\operatorname{MAX}-\mathrm{IO}(\mu)$ \\
\hline a. [mwu $2 . s i]$ & & $* !$ & & & & $*$ \\
\hline b. $\quad\left[\mathrm{m}^{\mathrm{w}} \mathrm{u}_{2} . \mathrm{si}\right]$ & & & $* !$ & & * & $*$ \\
\hline c. $\left[\mathrm{mu}_{2} . \mathrm{si}\right]$ & & & & & $*$ & * \\
\hline d. $\quad\left[\mathrm{mu}_{1} \cdot \mathrm{u}_{2} \cdot \mathrm{si}\right]$ & $* !$ & & & & & \\
\hline e. $\quad\left[\mathrm{mu}_{1} . \mathrm{si}\right]$ & & & & $* !$ & * & * \\
\hline
\end{tabular}

In Tableau 6, the optimal candidate (c) elides $\mathrm{V}_{1} / \mathrm{u} /$ to resolve hiatus, which results in a nonfatal violation of the low-ranking faithfulness constraints $\operatorname{MAX}-\operatorname{IO}(\mathrm{RT})$ and $\operatorname{MAX}-\operatorname{IO}(\mu)$. Candidate (a) employs glide formation, which results in a complex onset and thus a fatal violation of *COMPLEX; it also involves a non-fatal violation of $\operatorname{MAX}-\mathrm{IO}(\mu)$. Candidate (b) labialises a bilabial nasal $/ \mathrm{m} /$, which in turn is followed by a labial vowel, resulting in a fatal violation of OCP. It is important to note here that labial dissimilation to create $*\left[\mathrm{y}^{\mathrm{w}} \mathrm{usi}\right]$ would also incur a violation of OCP, as it would again result in a disallowed sequence of a labialised consonant followed by a labial vowel. The penultimate candidate (d) is fully faithful in fatal violation of No-HIATUS. Finally, (e) involves the elision of $\mathrm{V}_{2}$, which is forbidden by the highranking ANCHOR L constraint; it also incurs violations of the two low-ranking MAX-IO constraints. Tableau 7 below illustrates the elision of /i/ as it occurs in the class 7 prefix $/ \int \mathrm{i}-/$, exemplified using (42) from Table $12 / \sqrt{1}-\mathrm{a}^{\mathrm{n}} \mathrm{ba} /$ 'cl7-hand'.

Tableau 7: Elision of /i/ following palatal fricative / $/$

\begin{tabular}{|c|c|c|c|c|c|c|}
\hline$/ \int 1$-antza/ & $\begin{array}{c}\text { No- } \\
\text { HIATUS }\end{array}$ & *COMPLEX & $\mathrm{OCP}$ & ANCHOR L & MAX-IO(RT) & $\operatorname{MAX}-\mathrm{IO}(\mu)$ \\
\hline$\left[\int j a .{ }^{n} \operatorname{lga}\right]$ & & $* !$ & & & & $*$ \\
\hline$\left[\int^{j} a \cdot{ }^{n} \mathrm{Ba}\right]$ & & & $* !$ & & $*$ & $*$ \\
\hline c. $\left[\int a \cdot{ }^{n} b a\right]$ & & & & & $*$ & $*$ \\
\hline $\begin{array}{ll}\text { d. } & {\left[\text { ji.a. }{ }^{n} \text { ba }\right.}\end{array}$ & $* !$ & & & & & \\
\hline $\begin{array}{ll}\text { e. } & {\left[\int{ }^{n}{ }^{n} \text { ba }\right]}\end{array}$ & & & & $* !$ & $*$ & $*$ \\
\hline
\end{tabular}

In Tableau 7, candidate (c) is the optimal candidate, as it only incurs two non-fatal violations of the two MAX-IO constraints in order to satisfy the higher-ranking constraints. Candidate (a) makes use of glide formation to eliminate vowel hiatus, resulting in a complex onset and, less importantly, the loss of a mora. Consequently, it is eliminated by *COMPLEX. Candidate (b) palatalises a palatal consonant $/ J /$, thus fatally violating OCP. Candidate (d) is fully faithful, resulting in a fatal violation of No-HIATUS; and (e) involves the elision of $\mathrm{V}_{2}$, which in turn fatally violates ANCHOR L. 
Xitsonga also involves the elision of /a/ when it appears in a noun class prefix, as in example (40) in Table 12. The segmental markedness constraint that prohibits the pharyngealisation of consonants is defined in (38) above. Xitsonga does not have such consonants in its inventory. Tableau 8 below illustrates how this constraint operates in conjunction with those already mentioned.

Tableau 8: Elision of /a/

\begin{tabular}{|cr|c|c|c|c|c|}
\hline & $/ \mathrm{va}_{1}-\mathrm{a}_{2} \mathrm{ki} /$ & $\begin{array}{c}\text { NO- } \\
\text { HIATUS }\end{array}$ & ${ }^{*} \mathrm{C}^{\mathrm{C}}$ & ANCHOR L & MAX-IO(RT) & MAX-IO $(\mu)$ \\
\hline a. & {$\left[\mathrm{v}^{\mathrm{C}} \mathrm{a}_{2} . \mathrm{ki}\right]$} & & $* !$ & & $*$ & $*$ \\
\hline b. & {$\left[\mathrm{va} \mathrm{a}_{1} \cdot \mathrm{ki}\right]$} & & & $* !$ & $*$ & $*$ \\
\hline c. & {$\left[\mathrm{va}_{2} . \mathrm{ki}\right]$} & & & & $*$ & $*$ \\
\hline d. & {$\left[\mathrm{va}_{1} . \mathrm{a}_{2} . \mathrm{ki}\right]$} & $* !$ & & & & \\
\hline
\end{tabular}

Candidate (c) is the optimal candidate, as it only incurs two low-ranking violations. Candidate (a) fatally violates $* \mathrm{C}^{\mathcal{S}}$, as it involves the pharyngealisation of the first consonant. Candidate (b), which deletes $\mathrm{V}_{2}$, is eliminated by ANCHOR L. Finally, candidate (d), which is the faithful parse, fatally violates No-HIATUS. Elision of $\mathrm{V}_{1}$ is also evident across the stem and suffix domain, for example when the diminutive suffix /-ana/ is added to a noun stem ending on a vowel (Lee and Burheni 2014).

Table 13: $\mathrm{V}_{1}$ elision in the formation of diminutives (Lee and Burheni 2014:90)

\begin{tabular}{|c|c|c|c|}
\hline & Input & & Output \\
\hline (45) & $\begin{array}{l}\text { / } 1 \text { i-saka-ana/ } \\
\text { CL7-grain bag-DIM }\end{array}$ & $\rightarrow$ & $\begin{array}{l}\text { [Jisakana] } \\
\text { 'small grain bag' }\end{array}$ \\
\hline (46) & $\begin{array}{l}\text { /Ji-mbuti-ana/ } \\
\text { CL7-goat-DIM }\end{array}$ & $\rightarrow$ & $\begin{array}{l}{\left[\int^{\mathrm{m}} \text { butana }\right]} \\
\text { 'small goat' }\end{array}$ \\
\hline (47) & $\begin{array}{l}\text { /si-seke-ana/ } \\
\text { CL8-sand-DIM }\end{array}$ & $\rightarrow$ & $\begin{array}{l}\text { [sisekana] } \\
\text { 'small sand' }\end{array}$ \\
\hline
\end{tabular}

Example (45) can be accounted for by Tableau 8 . In other words, the /a/ of the noun stem $\left(\mathrm{V}_{1}\right)$ is elided rather than participating in secondary articulation, as pharyngealised consonants are prohibited due to the high rank of the constraint $* C^{\mathcal{S}}$. Example (46) involves vowel deletion rather than palatalisation, as the latter is only triggered when the consonant preceding $\mathrm{V}_{1}$ is $/ \mathrm{l} \mathrm{r}$ $\mathrm{v}^{\mathrm{m}} \mathrm{b} /{ }^{4}$ Example (47) involves elision of /e/ in the noun stem when the preceding consonant is $/ \mathrm{k} /$. This does not involve secondary articulation, as one might expect, for two reasons: first, as mentioned above, palatalisation only occurs when the preceding consonant is $/ 1 \mathrm{r} \mathrm{v} \mathrm{m} /$. Secondly, velar consonants cannot be palatalised due to a segmental markedness constraint defined in (48) below, which essentially means that these types of segments cannot be found in the segment inventory of Xitsonga:

$$
\begin{aligned}
& * \mathrm{C}_{\text {[velar }}{ }^{\mathrm{j}} \\
& \text { No palatalised velar consonants }
\end{aligned}
$$

\footnotetext{
${ }^{4}$ This is the context in which affrication occurs in the dialect discussed by Lee and Burheni (2014:99).
} 
The effect of this co-occurrence constraint is demonstrated in Tableau 9 below.

Tableau 9: Elision of /e/ following / $\mathrm{k} /$

\begin{tabular}{|c|c|c|c|c|c|c|c|}
\hline /si-seke-ana/ & $\begin{array}{l}\text { No- } \\
\text { HiATUS }\end{array}$ & *COMPLEX & $* \mathrm{C}_{[\text {velar }}{ }^{\mathrm{j}}$ & $* \mathrm{C}^{\complement}$ & $\begin{array}{l}\text { ANCHOR } \\
\mathrm{L}\end{array}$ & $\begin{array}{l}\text { MAX- } \\
\text { IO(RT) }\end{array}$ & $\begin{array}{l}\text { MAX- } \\
\mathrm{IO}(\mu)\end{array}$ \\
\hline a. $[$ si.se.ka.na] & & & & & & $*$ & $*$ \\
\hline b. [si.se.ke.a.na] & $* !$ & & & & & & \\
\hline c. [si.se.kja.na] & & $* !$ & & & & & $*$ \\
\hline d. [si.se.ke.na] & & & & & $* !$ & & \\
\hline e. $\quad$ [si.se.k ${ }^{j}$ a.na] & & & $* !$ & & & $*$ & $*$ \\
\hline
\end{tabular}

Candidate (a) is the winner. It deletes $\mathrm{V}_{1}$. As a result, it satisfies all the high-ranking constraints. Candidate (b), which is fully faithful, fatally violates No-HIATUs; while candidate (d) violates ANCHOR $L$ by deleting $V_{2}$. Glide formation when $V_{1}$ is preceded by a consonant incurs a fatal violation of *COMPLEX, as in candidate (c). Candidate (e) fatally violates the newly-introduced constraint prohibiting the occurrence of palatalised velar consonants $* \mathrm{C}_{[\text {velar }}{ }^{\mathrm{j}}$.

From the analysis of $\mathrm{V}_{1}$ elision thus far, it is evident that unrounded vowels are most likely to be deleted, while rounded vowels participate in secondary articulation (labialisation). Rounded vowels are only elided in order to satisfy OCP, as will become evident in the next part of the analysis. Still, in our examination of the formation of diminutives, if the stem-final vowel is rounded /o u/ and is preceded by an oral labial consonant, the round vowel $\left(\mathrm{V}_{1}\right)$ is deleted (see Lee and Burheni 2014 for detailed discussion). Table 14 provides examples of this particular instance of $\mathrm{V}_{1}$ elision.

Table 14: $\mathrm{V}_{1}$ elision of rounded vowels (diminutives)

\begin{tabular}{|c|c|c|c|}
\hline & Input & & Output \\
\hline (49) & $\begin{array}{l}/ \int \mathrm{i} \text {-sefo-ana/ } \\
\text { CL7-sieve-DIM }\end{array}$ & $\rightarrow$ & $\begin{array}{l}\text { [Jisefana] } \\
\text { 'small sieve' }\end{array}$ \\
\hline$(50)$ & $\begin{array}{l}\text { //fi-hafu-ana/ } \\
\text { CL7-half-DIM }\end{array}$ & $\rightarrow$ & $\begin{array}{l}\text { [Jihafana] } \\
\text { 'small half' }\end{array}$ \\
\hline
\end{tabular}

An analysis of one of the examples from Table 14 above will suffice to account for this elision (as opposed to the more desirable secondary articulation in the form of labialisation). In order to account for the elision of labial vowels when preceded by labial obstruents, as illustrated in examples (49) and (50), a faithfulness constraint as in (51) is required.

\section{IDENT-IO(PLACE) OBSTRUENT}

The place feature of obstruents in the input is preserved in the output.

Unlike IDENT-IO(PLACE) NASAL, which is low-ranking, the identity constraint defined in (51) is high-ranking, thus prohibiting obstruents like /f/ from changing their place of articulation in the output. While Lee and Burheni (2014:97) use the segmental markedness constraint $*[\mathrm{x}]$ to ban the realisation of /f/ as [x], we prefer the identity constraint in (51) because it is more general. 
Tableau 10: Elision of rounded vowel following labial obstruent

\begin{tabular}{|c|c|c|c|c|c|c|c|}
\hline$/ \int 1-s e f o-a n a /$ & $\begin{array}{c}\text { No- } \\
\text { HIATUS }\end{array}$ & *COMPLEX & OCP & $\begin{array}{c}\text { ANCHOR } \\
\text { L }\end{array}$ & $\begin{array}{c}\text { IDENT- } \\
\text { IO(PLACE) } \\
\text { OBSTRUENT }\end{array}$ & $\begin{array}{l}\text { MAX- } \\
\text { IO(RT) }\end{array}$ & $\begin{array}{l}\text { MAX- } \\
\mathrm{IO}(\mu)\end{array}$ \\
\hline a. Ji.se.fo.a.na & $* !$ & & & & & & \\
\hline b. Ji.se.fwa.na & & $* !$ & & & & & $*$ \\
\hline c. $\quad$ ji.se. $\mathrm{f}^{\mathrm{w}} \mathrm{a} \cdot \mathrm{na}$ & & & $* !$ & & & $*$ & $*$ \\
\hline d. $\quad$ fi.se. $x^{\mathrm{w}}$ a.na & & & & & $* !$ & $*$ & $*$ \\
\hline e. $\quad \int i . s e . f a . n a$ & & & & & & $*$ & $*$ \\
\hline f. $\quad$ fi.se.fo.na & & & & $* !$ & & $*$ & $*$ \\
\hline
\end{tabular}

Tableau 10 presents six possible output candidates, of which (e) is the optimal one as it incurs only violations of low-ranking constraints. Candidate (a) fatally violates No-HIATUS, as it is fully faithful; (b) contains a complex onset as a result of glide formation, thus crucially violating *COMPLEX. Candidate (f) fatally violates ANCHOR L due to $\mathrm{V}_{2}$ elision. Most importantly in this case is candidate (c), which incurs a fatal violation of OCP by labialising a labial consonant. Additionally, candidate (d), in which the /f/ surfaces as [x], is disqualified, as it incurs a fatal violation of IDENT-IO(PLACE) OBSTRUENT. In all of the cases presented in Table 14, the stemfinal rounded vowel is deleted rather than triggering secondary articulation, in an effort to preserve the satisfaction of OCP and IDENT-IO(PLACE) OBSTRUENT.

\section{Conclusion}

This article presented a consolidated and comprehensive analysis of vowel hiatus resolution in Xitsonga, using OT. As expected, the language conforms to the norm of vowel hiatus resolution strategies in other Bantu languages, all in an effort to satisfy No-HIATUS. Glide formation is the optimal repair strategy, as it preserves most of the features of $\mathrm{V}_{1}$. The data illustrate that /i/ becomes the glide [j], and / $\mathrm{u} /$ the glide [w]. When glide formation is blocked by *COMPLEX, secondary articulation in the form of labialisation and palatalisation is triggered. In Xitsonga, mid-vowels /o e/ also participate in secondary articulation. This is an interesting phenomenon, as it is uncommon for non-high vowels to trigger secondary articulation in Southern Bantu languages. The role of OCP is vital in Xitsonga and is often the driving force behind the choice of one strategy over another. Labialisation is tolerated following non-labial consonants, but an OCP-driven process of labial dissimilation in the form of velarisation of the nasal is triggered when the preceding consonant is the bilabial nasal $/ \mathrm{m} /$. Palatalisation occurs accompanied by phonetic changes in the forms $/ 1 \mathrm{r} / \rightarrow[\mathrm{d}]$ and $/ \mathrm{v} / \rightarrow[\mathrm{b}]$. This repair strategy incurs a non-fatal violation of IDENT-IO (MANNER). Vowel elision occurs as the least preferred strategy, always driven by OCP and segmental markedness demands. Deletion regularly occurs in order to prevent the labialisation of labial consonants and the palatalisation of palatal consonants. Vowel coalescence occurs in Xitsonga and takes two forms, /a $+\mathrm{i} / \rightarrow[\mathrm{e}]$ and /a $+\mathrm{u} / \rightarrow[\mathrm{o}]$, both of which incur a non-fatal violation of UNIFORMITY. When coalescence cannot occur due to a disallowed sequence of $/ \mathrm{a} /$ and another vowel that is not $/ \mathrm{i} /$ or $/ \mathrm{u} /$, the $/ \mathrm{a} /$ is elided. This is because the low vowel /a/ cannot be turned into secondary articulation (pharyngealisation) or a low glide. The constraint ranking that determines the operation of hiatus resolution in Xitsonga is given in (52) below: 
(52) Ultimate constraint ranking of Xitsonga:

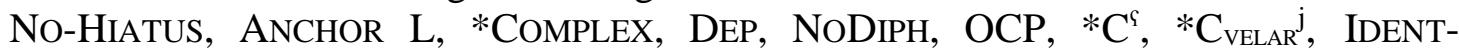
IO(PLACE) OBSTRUENT > MAX-IO(RT) > MAX-IO( $\mu$ ), IDENT-IO(PLACE) NASAL, IDENT-IO (MANNER), ${ }^{*} \mathrm{C}^{\mathrm{j}}$, UNIFORMITY

Every repair strategy employed to resolve vowel hiatus violates $\operatorname{Max}-\mathrm{IO}(\mu)$, and everyone but glide formation violates Max-IO(Rt). Labialisation with labial dissimilation, palatalisation, and vowel coalescence incur a further violation of IDENT-IO; and coalescence incurs a non-fatal violation of UNIFORMITY. The efficacy of the constraint ranking in (52) is illustrated in Tableau 11 below.

Tableau 11. Summary of constraint ranking and vowel hiatus resolution strategies

\begin{tabular}{|c|c|c|c|c|c|c|c|c|c|c|c|c|c|c|c|c|}
\hline $\begin{array}{l}\text { Vowel hiatus } \\
\text { resolution } \\
\text { strategy }\end{array}$ & $\begin{array}{c}\begin{array}{c}\text { Constraints } \\
\rightarrow\end{array} \\
\begin{array}{c}\text { Optimal } \\
\text { candidates } \downarrow\end{array}\end{array}$ & $\begin{array}{l}n \\
2 \\
0 \\
\vdots \\
0 \\
0 \\
\vdots\end{array}$ & 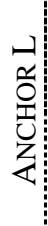 & 敎 & 苛 & $\begin{array}{l}\mathbf{1} \\
\text { Oे } \\
0 \\
\vdots\end{array}$ & ○े: & $\circlearrowright_{*}$ & 占预 & 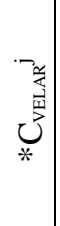 & 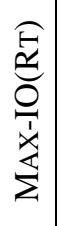 & 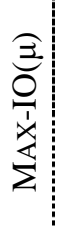 & 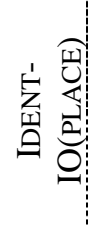 & 岂 & 点 & $\circlearrowright_{*}$ \\
\hline Glide formation & [je.na] & & & & & & & & & & & $*$ & & & & \\
\hline Labialisation & 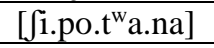 & & & & & & & & & & $*$ & $*$ & & & & \\
\hline $\begin{array}{l}\text { Labialisation } \\
\text { with labial } \\
\text { dissimilation }\end{array}$ & [ji.go.n ${ }^{\mathrm{w}}$ a.na $]$ & & & & & & & & & & $*$ & $*$ & $*$ & & & \\
\hline Palatalisation & [ $\left.\int i . t \int u . d^{j} a . n a\right]$ & & & & & & & & & & $*$ & $*$ & & & $*$ & $*$ \\
\hline $\begin{array}{l}\text { Vowel } \\
\text { coalescence }\end{array}$ & [me.nu] & & & & & & & & & & $*$ & $*$ & & $*$ & & \\
\hline Vowel elision & [mu.si] & & & & & & & & & & $*$ & $*$ & & & & \\
\hline
\end{tabular}

It is hoped that this study has presented a cohesive analysis of previously fragmented data illustrating vowel hiatus resolution in Xitsonga.

\section{References}

Archangeli, D. 1997. Optimality Theory: An introduction to linguistics in the 1990s. In D. Archangeli and D. T. Langendoen (eds.) Optimality Theory: An overview. Oxford: Blackwell Publishers. pp. 1-32.

Baumbach, E. 1974. Introduction to the speech sounds and speech sound changes of Tsonga. Pretoria: J.L. van Schaik Ltd.

Baumbach, E. 1987. Analytical Tsonga-English dictionary. s.1.: Self-publication.

Casali, R. 2011. Hiatus resolution. In M. van Oostendorp, C. Ewen, E. Hume and K. Rice (eds.) The Blackwell companion to phonology. Malden, MA and Oxford: Wiley Blackwell Publishers. pp. 1434-1460.

Cole-Beuchat, P.-D. 1961. The qualificative and the pronoun in Tsonga. African Studies 20(3): 175-193. 
Cuenod, R. 1982. Tsonga-English Dictionary. Johannesburg: Sasanova Books.

Guthrie, M. 1971. Comparative Bantu. London: Gregg Press.

Harford, C. 1997. When two vowels go walking: Vowel coalescence in Shona. Zambezia 24(1): $69-85$.

Janson, T. 2001. Consonants in Changana/Tsonga. South African Journal of African Linguistics 21(1): 16-32.

Kadenge, M. 2015. The augment and $\{$ mu- $\}$ reduction in Bantu: An Optimality Theory analysis. South African Journal of African Linguistics 35(1): 93-105.

Kadenge, M. and S.R. Simango. 2014. Comparing vowel hiatus resolution in ciNsenga and chiShona: An Optimality Theory analysis. Stellenbosch Papers in Linguistics Plus 44: 105-127.

Kager, R. 1999. Optimality Theory. Cambridge: Cambridge University Press.

Lee, S.J. 2009. H tone, depressors and downstep in Tsonga. In M. Matondo, F. McLaughlin and E. Potsdam (eds.) Selected proceedings of the $38^{\text {th }}$ Annual Conference on African Linguistics: Linguistic Theory and African Language Documentation. Somerville, MA: Cascadilla Proceedings Project. pp. 26-37.

Lee, S. 2015. Cumulative effects in Xitsonga: High-tone spreading and depressor consonants. Southern African Linguistics and Applied Language Studies 33(3): 273-290.

Lee, S. J. and C. Burheni. 2014. Repair strategies in labial dissimilation: Diminutive formations in Xitsonga. Stellenbosch Papers in Linguistics Plus 44: 89-103.

McCarthy, J. 1988. Feature geometry and dependency: A review. Phonetica 43: 84-108.

Miti, L. 2001. A linguistic analysis of Cinsenga: A Bantu language spoken in Zambia and Malawi. Cape Town: Centre for Advanced Studies of African Society (CASAS) Book Series.

Miti, L. 2002. Comparative Bantu phonology and morphology. Cape Town: CASAS Book Series 16.

Mudzingwa, C. 2010. Shona morphophonemics: Repair strategies in Karanga and Zezuru. Doctoral dissertation. Vancouver: University of British Columbia.

Mudzingwa, C. and M. Kadenge. 2011. Comparing hiatus resolution in Karanga and Nambya: An Optimality Theory account. Nordic Journal of African Studies 20(3): 203-240.

Mudzingwa, C. and M. Kadenge. 2014. Coalescence as a hiatus resolution strategy in chiKaranga - a dialect of chiShona. South African Journal of African Languages 34(2): 127 136.

Odden, D. 2015. Bantu Linguistics. Available online: http://www.oxfordhandbooks.com/ 
Prince, A. and P. Smolensky. 2004. Optimality Theory: Constraint interaction in generative grammar. Malden, Mass.: Routledge.

Pulleyblank, D. 1997. Optimality Theory and features. In D. Archangeli and D.T. Langendoen (eds.) Optimality Theory: An overview. Malden, Mass: Blackwell. pp. 59-101.

Rosenthall, S. 1997. The distribution of prevocalic vowels. Natural Language \& Linguistic Theory 15(1): 139-180.

Sibanda G. 2009. Vowel sequences in Nguni: Resolving the problem of unacceptable VV sequences. In M. Matondo, F. McLaughlin and E. Potsdam (eds.) Selected proceedings of the $38^{\text {th }}$ Annual Conference on African Linguistics: Linguistic Theory and African Language Documentation. Somerville, MA: Cascadilla Proceedings Project. pp. 38-55.

Simango, R. and M. Kadenge. 2014. Vowel hiatus resolution in Nsenga: An Optimality Theory analysis. Southern African Linguistics and Applied Lanaguage Studies 32(1): 79-96.

van der Spuy, A. 1990. Phonological relationships between the Southern Bantu languages. African Studies 49(1): 119-147.

van Wyk, E. 1957. An augmentative noun class in Tsonga. African Studies 16(1): 25-36.

van Wyk, E. B., F.F. Odendaal and N.L. Nkatini. 1989. Fonologiese sisteme van Afrikaans en Tsonga: 'n Vergelyking. South African Journal of Linguistics 7(1): 38-45.

Zerbian, S. 2007. A first approach to information structuring in Xitsonga/Xichangana. SOAS Working Papers in Linguistics 15: 65-78. 